Research, National Research Council, Ottawa. Other members of the Committee are: H. J. Butterill (Intermational Nickel Co.), N. Cohen (National Research Council), R. Judge (Department of National Defence, representing the Defence Research Board), Frank D. Forward (University of British Columbia), H. P. Godard (Aluminium Laboratories, Ltd.), Lorne Sproule (Imperial Oil Ltd.), Dr. C. Y. Hopkins (National Research Council), E. T. Hurley (Canadian National Railways), H. D. Smith (Nova Scotia Research Foundation), and Frank Twining (Canadian Industries, Ltd.).

\section{'Supermalloy' : a New Magnetic Alloy}

InoN-nickel alloys, containing 35-90 per cent nickel, have permeabilities very much greater than that of iron. These alloys, called 'permalloys', are especially useful commercially for transformers. The addition of one or more of the elements molybdenum, chromium and copper to permalloys has proved advantageous. 'Mumetal', which contains usually 5 per cent copper, 2 per cent chromium, 75 per cent nickel and 18 per cent iron, is perhaps the best known of the permalloys. It is used in transformers suitable for high frequencies and is notable not only for its high initial permeability (between 10,000 and 30,000 ) and its high electrical resistivity $(60 \mathrm{microhm}$. $\mathrm{cm}$.) but also for the very simple heat treatment required in its preparation. O. L. Boothby and R. M. Bozorth have described recent developments in these highnickel alloys for use at low inductions ( $J$. A ppl. Phys., 18, 173 ; 1947 ; see also Bozorth, R. M., Rev. Mod. Phys., 19, 38; 1947). The now material 'Supermalloy' (su-perm'-al-loy), developed during the Second World War and already supplied in considerable quantities to the U.S. Navy, contains 5 per cent molybdenum and 79 per cent nickel, the remainder being mainly iron with a little manganese. The alloy is heat-treated, being maintained at $1,300^{\circ} \mathrm{C}$. in pure dry hydrogen and then cooled from $600^{\circ} \mathrm{C}$. to $300^{\circ} \mathrm{C}$. at a critical rate. Whereas its electrical resistivity is about the same as for 'Mumetal', its initial and maximum permeabilities are many times larger, 50,000-150,000 for the initial, and 600,000$1,200,000$ for the maximum, permeabilities. 'Supermalloy' can be produced in the form of very thin insulated tape, suitable for transformer cores, and it is claimed that the use of this new alloy in communication transformers permits a threefold increase in the range of frequencies transmitted, and a pulse duration three times that previously obtained.

\section{Colchicine, its Chemical and Biological Properties}

THE sessional inaugural lecture to the Chemical Society of University College, Dublin, was delivered on February 3 by Prof. J. W. Cook, regius professor of chemistry, University of Glasgow, who spoke on colchicine. Colchicum, a drug of great antiquity, is extracted from meadow saffron (Colchicum autumnale). It is present in all parts of the plant, especially in the seeds, which contain up to 0.75 per cent of the active principle. The poisonous nature of colchicum was known to Dioscorides; its toxic symptoms and its only therapeutic use, in the treatment of gout, are described in "The Herball", by John Gerarde, published in 1597. Colchicine, the active principle of colchicum, was isolated by Pelletier in 1820 , but was not obtained pure and crystalline until 1915. Its composition and its functional groups were investig. ated by Zeisel, and the main features of its molecular structure were established by Windaus in 1924.
Colchicine, $\mathrm{C}_{22} \mathrm{H}_{25} \mathrm{O}_{6} \mathrm{~N}$, contains three rings, one of them a trimethoxylated benzene ring, an acetylamino group, and an inert carbonyl group, and it is the methyl ether of an enol. Recent studies have shown that revision of the Windaus structure is necessary, and the molecular formula of a degradation product, deaminocolchinol methyl ether, has been established beyond doubt by Barton, Cook and Loudon (1945). The final details of structure of colchicine itself still require to be settled. The molecule probably contains at least one seven-membered carbon ring. The remarkable effect of colchicine in arresting mitosis in nuclei at the metaphase was discovered by Lits, a pupil of Dustin; it is effective in a dilution of 1 in $10^{8}$, and has important biological applications. Thus, it may be used as an index of the rate of growth of tissues, and of the activity of various classes of growth-stimulating hormones. An effect on plants, first studied by Havas, was shown by extensive investigations of Blakeslee to result in the production of polyploidy, leading to new and improved varieties of flowers, fruits and cereals.

\section{Insect Pests of Flour}

UNDER the title of "Insect Pests of Food: The Control of Insects in Flour Mills" (London : H.M. Stationery Office. 7s. 6d. net), the Ministry of Food has recently issued a useful 84-page practical bulletin by J. A. Freeman and E. E. Turtle. The authors are, respectively, chief entomologist and chief chemist of the Infestation Control Division of the Ministry. The bulletin deals with those insects and mites that affect the flour miller: it describes the measures that can be adopted in order to prevent infestation and how to control such insects should they manage to establish themselves. It is divided into three main sections, namely, methods of prevention and control; life-histories of insects and mites; and infestation in the mill. The losses which these creatures inflict on the industry may be assessed as damage to wheat; interference with productive processes; contamination and spoiling of finished products and loss of goodwill and trade.reputation. The methods of control that are described are only those which have been examined by the Ministry and thoroughly proved in practice. It should not be inferred, however, that these methods are in any sense static. New work is continually going on, and, as examples, may be mentioned that which is being done in assessing the value of D.D.T. and of benzene hexachloride ('Gammexane') in this connexion. The bulletin is very well illustrated by numerous halftone plates and text-figures.

\section{The Bird Watcher}

THE company of bird watchers grows larger with succeeding years, its ranks including a diversity of enthusiasts, from the scientific ornithologist to the schoolboy and schoolgirl recruit. It is to help these latter that the Daily Mail has issued a number of booklets on Nature subjects and so on, the latest of its School Aid series being "Bird Watching" by Mr. Stuart Smith $(2 s$.$) . This consists of some thirty-four$ pages of excellent advice on how to study birds, with a number of admirable photographs by $\mathrm{Mr}$. Eric Hosking, supplemented by equally admirable drawings by Mr. Edward Bradbury and eight colour pictures, the latter being reproductions of plates from Gould's "Birds of Great Britain". It is wonderful how fresh in spirit and treatment the Gould bird portraits remain, while for accuracy of feather detail 
they are hard to beat. With regard to the letterpress, Mr. Stuart Smith's advice on bird-watching will be very helpful to young people, especially his hints on identifying birds in the field; in short, his book is not only a good addition to the School Aid series, but is to be recommended for any boy or girl who shows an inclination for bird study.

\section{The Caribbean Commission}

THE Caribbean Commission, instituted by the Governments of France, the Netherlands, the United Kingdom and the United States, has published its first annual report (Port of Spain : Caribbean Commission. London: Crown Agents for the Colonies). From the scientific point of view its most important work is that of the Caribbean Research Council. The Commission is a consultative and advisory body fully representative of all the Colonies (islands and mainland) in the Caribbean area. Its Research Council is specially concerned with scientific, technological, social and economic problems. After its war activ. ities, concerned largely with provision and distribution of food to the various Colonies, the Commission and its various committees are now again getting down to work. Problems of forestry, livestock, grain crops and grassland have been investigated or are under investigation. The Commission has also been concerned with the transference of West Indian agricultural labour to the United States.

\section{Ray Society: Annual General Meeting}

THe hundred and fourth annual general meeting of the Ray Society was held on March 17. It was announced that Pennant's "Tour on the Continent 1765", edited by Prof. G. R. de Beer, would be published shortly as part of the issue to members for 1947, and other volumes relating to the British fauna and flora are in active preparation, including Prof. Berrill's work on the Tunicates, Mr. Dandy's volume on British vice-counties, Messrs. Locket and Millidge's "British Spiders", the late Prof. W. M. 'Tattersall's monograph on the Mysidacea, and a second volume of Prof. Balfour-Browne's "British Water Beetles". The greatly increased cost of printing is likely seriously to hamper the activities of the Society, and an urgent appeal is made for new subscribers-both institutions and individuals. Prof. G. R. de Beer, Mr. A. C. Townsend and Dr. Errol White were re-elected president, honorary treasurer and honorary secretary respectively; Capt. C. Diver and Dr. W. S. Bristowe were elected vice-presidents and Dr. Malcolm Smith, Dr. John Hutchinson, Major Maxwell Knight and Dr. Ethelwynn Trewavas new members of council.

\section{Summer School in X-Ray Crystallography}

A Summer Schoor in fundamental and applied $\mathrm{X}$-ray crystallography will be held in the College of Technology, Manchester, during September 6-17. The course will be conducted by Dr. H. Lipson, Dr. H. E. Buckley and other members of the staff of the University and the College of Technology. During the course emphasis will be laid upon fundamentals such as the analysis of the basic types of $\mathrm{X}$-ray photograph, and enough detail will be given to enable the student to deal with more advanced types by himself ; in addition, directions of practical application will be indicated. It is hoped that, by these methods, students will have received a clear outline of the application of X-ray methods in general and that they will thus be able to assess its value to their own researches in particular. Applications to attend the course should be sent to the Director of Extra-Mural Studies, University, Manchester 13, and must be received not later than May 12.

\section{Announcements}

WE regret to announce the death of Prof. Alfred Lacroix, For.Mem.R.S., permanent secretary for thirty-four years of the Paris Academy of Sciences, on March 16, aged eighty-five; and of Prof. E. Waymouth Reid, F.R.S., professor of physiology at University College, Dundee, during 1889-1935, on March 10, aged eighty-five.

THE honorary degree of doctor of laws has been conferred by the University of Aberdeen on Sir George Thomson, professor of physics, Imperial College of Science and Technology, London; and on Major-General D. N. Wimberley, principal of University College, Dundee.

ON the occasion of the installation of Lord Halifax as chancellor of the University of Sheffield on July 2 , the honorary degree of doctor of laws will be conferred on the following : The Hon. Lewis W. Douglas, Ambassador for the United States of America; Mr. Anthony Eden; Lord Addison; Admiral of the Fleet Lord Cunningham; Sir Frank Stenton, vicechancellor of the University of Reading ; Sir Henry Tizard, chairman of the Advisory Council on Scientific Policy; and Mr. Ernest S. Graham, Lord Mayor of Sheffield, 1946-47.

Dr. V. Petrow, lecturer in chemistry at Queen Mary College, University of London, has been appointed chief research chemist to the British Drug Houses, Ltd., London, in succession to Dr. W. Bradley, who has accepted an invitation to the chair of colour chemistry and dyeing in the University of Leeds.

A PRELIMINARy meeting with the view of the establishment of a Scottish Society of the History of Medicine will be held in the Library of the Royal College of Surgeons, Edinburgh, on April 23, at 5 p.m. Dr. Douglas Guthrie will make a statement regarding the constitution and object of the proposed Society, and a paper by Dr. Henry J. C. Gibson on "The Early Days of Dundee Royal Infirmary" will be read. Communications should be sent to Dr. Douglas Guthrie, 21 Clarendon Crescent, Edinburgh.

THe National Research Council of Canada has established post-doctorate fellowships in pure chemistry tenable in its laboratories in Ottawa. The normal stipend will be 2,820 dollars, but may be varied depending on the qualifications of the candidate. A travelling allowance may be made. The awards are tenable for a period of one year but may be renewed for a second year. The subjects for investigation include photochemistry, radiation chemistry, spectroscopy, organic chemistry, radioactivity, low-temperature investigations, surface chemistry, and the properties of gases at high pressures and temperatures. Information and application forms may be obtained from the Chief Scientific Liaison Officer, Canada House, London, S.W.1.

Errata. In the note on the Max Planck Society in Nature of March 20, p. 427, the president's name should have been Prof. Erich Regener; misprints also appear in the names of Prof. Georg Schreiber and Prof. Heinrich Wieland. 